\title{
Does neuroinflammation fan the flame in neurodegenerative diseases?
}

\author{
Tamy C Frank-Cannon ${ }^{1}$, Laura T Alto ${ }^{2}$, Fiona E McAlpine ${ }^{3}$ and \\ Malú G Tansey*4
}

Address: ${ }^{1}$ Department of Veterinary Integrative Biosciences, College of Veterinary Medicine \& Biomedical Sciences, Texas A\&M University, College Station, TX 77843, USA, 2Department of Physiology, The University of Texas Southwestern Medical Center, Dallas, TX 75390, USA, ${ }^{3}$ Cancer Research UK London Research Institute, 44 Lincolns Inn Fields, WC2A 3PX, UK and ${ }^{4}$ Department of Physiology, Emory University School of Medicine, Atlanta, GA 30322, USA

Email: Tamy C Frank-Cannon - TFrank-Cannon@cvm.tamu.edu; Laura T Alto - laura.alto@utsouthwestern.edu; Fiona E McAlpine - fiona.mcalpine@cancer.org.uk; Malú G Tansey* - malu.tansey@emory.edu

* Corresponding author

This article is available from: http://www.molecularneurodegeneration.com/content/4///47

(C) 2009 Frank-Cannon et al; licensee BioMed Central Ltd.

This is an Open Access article distributed under the terms of the Creative Commons Attribution License (http://creativecommons.org/licenses/by/2.0), which permits unrestricted use, distribution, and reproduction in any medium, provided the original work is properly cited.

\begin{abstract}
While peripheral immune access to the central nervous system (CNS) is restricted and tightly controlled, the CNS is capable of dynamic immune and inflammatory responses to a variety of insults. Infections, trauma, stroke, toxins and other stimuli are capable of producing an immediate and short lived activation of the innate immune system within the CNS. This acute neuroinflammatory response includes activation of the resident immune cells (microglia) resulting in a phagocytic phenotype and the release of inflammatory mediators such as cytokines and chemokines. While an acute insult may trigger oxidative and nitrosative stress, it is typically shortlived and unlikely to be detrimental to long-term neuronal survival. In contrast, chronic neuroinflammation is a long-standing and often self-perpetuating neuroinflammatory response that persists long after an initial injury or insult. Chronic neuroinflammation includes not only longstanding activation of microglia and subsequent sustained release of inflammatory mediators, but also the resulting increased oxidative and nitrosative stress. The sustained release of inflammatory mediators works to perpetuate the inflammatory cycle, activating additional microglia, promoting their proliferation, and resulting in further release of inflammatory factors. Neurodegenerative CNS disorders, including multiple sclerosis (MS), Alzheimer's disease (AD), Parkinson's disease (PD), Huntington's disease (HD), amyotrophic lateral sclerosis (ALS), tauopathies, and age-related macular degeneration (ARMD), are associated with chronic neuroinflammation and elevated levels of several cytokines. Here we review the hallmarks of acute and chronic inflammatory responses in the CNS, the reasons why microglial activation represents a convergence point for diverse stimuli that may promote or compromise neuronal survival, and the epidemiologic, pharmacologic and genetic evidence implicating neuroinflammation in the pathophysiology of several neurodegenerative diseases.
\end{abstract}




\section{Overview}

Once considered an immune-privileged site because of the presence of the blood brain barrier (BBB), it is now clear that while peripheral immune access to the central nervous system (CNS) is restricted and tightly controlled, the CNS is capable of dynamic immune and inflammatory responses to a variety of insults [1]. Infections, trauma, stroke, toxins and other stimuli are capable of producing an immediate and short lived activation of the innate immune system within the CNS [2,3]. This acute neuroinflammatory response includes activation of the resident immune cells (microglia) resulting in a phagocytic phenotype and the release of inflammatory mediators such as cytokines and chemokines [4]. While an acute insult may trigger oxidative and nitrosative stress, it is typically short-lived and unlikely to be detrimental to longterm neuronal survival. Therefore, it is believed that an acute neuroinflammatory response is generally beneficial to the CNS, since it tends to minimize further injury and contributes to repair of damaged tissue.

In contrast, chronic neuroinflammation is a long-standing and often self-perpetuating neuroinflammatory response that persists long after an initial injury or insult. Chronic neuroinflammation includes not only longstanding activation of microglia and subsequent sustained release of inflammatory mediators, but also results in increased oxidative and nitrosative stress [4]. The sustained release of inflammatory mediators works to perpetuate the inflammatory cycle, activating additional microglia, promoting their proliferation, and resulting in further release of inflammatory factors. Owing to the chronic and sustained nature of the inflammation, there is often compromise of the BBB which increases infiltration of peripheral macrophages into the brain parenchyma to further perpetuate the inflammation [1]. Rather than serving a protective role as does acute neuroinflammation, chronic neuroinflammation is most often detrimental and damaging to nervous tissue. Thus, whether neuroinflammation has beneficial or harmful outcomes in the brain may depend critically on the duration of the inflammatory response.

Neurodegenerative CNS disorders, including multiple sclerosis (MS), Alzheimer's disease (AD), Parkinson's disease (PD), Huntington's disease (HD), amyotrophic lateral sclerosis (ALS), tauopathies, and age-related macular degeneration (ARMD), are associated with chronic neuroinflammation and elevated levels of several cytokines [5-8]. Neuropathological and neuroradiological studies indicate that neuroinflammatory responses may begin prior to significant loss of neuronal populations in the progression of these diseases. While there is no evidence to support a role for any particular cytokine in the direct triggering of any of these neurodegenerative conditions, cytokine-driven neuroinflammation and neurotoxicity may modify disease progression in a number of these disorders. For example, inflammatory challenges might act as triggers to uncover pre-existing genetic vulnerabilities that contribute to neuronal dysfunction and death. Alternatively, viruses or bacteria might "prime" the immune system to respond aberrantly to subsequent environmental challenges. The purpose of this article is to review the evidence that microglial activation represents a convergence point for diverse external stimuli that promote neuronal dysfunction and hasten neuronal death, and the epidemiologic, pharmacologic and genetic evidence implicating neuroinflammation in the pathophysiology of several neurodegenerative diseases. If the available evidence supports a role for neuroinflammation in any of these diseases, it may be possible to alter the course of disease development in afflicted individuals with timely delivery of anti-inflammatory therapy.

\section{Microglia activation: convergence point for diverse stimuli that compromise neuronal survival}

Microglia are the resident tissue macrophages in the central nervous system and are the principle mediators of inflammation. In the resting state, microglia display a small cell soma and numerous branching processes (a ramified morphology). In healthy brain tissue, these processes are dynamic structures that extend and retract sampling and monitoring their microenvironment (Nimmerjahn 2005, Raivich 2005). During the resting state several key surface receptors are expressed at low levels; these include the tyrosine phosphatase (CD) 45 (also known as leukocyte common antigen), CD-14, and CD11b/CD18 (Mac-1) (Kreutzberg 1996). In addition cell surface receptor-ligand pairs such as CD200R/CD200 are present to maintain neuron-glia communication in the CNS (Hock 2000, Cardona 2006).

In the presence of an activating stimulus, microglial cellsurface receptor expression is modified and the cells change from a monitoring role to one of protection and repair (reviewed in $[4,9]$ ). In addition to up-regulation of the key surface receptors mentioned above, there is upregulation of proteins such as $\mathrm{CD} 1$, lymphocyte functionassociated antigen 1 (LFA-1), intercellular adhesion molecule 1 (ICAM-1 or CD54), and vascular cell adhesion molecule (VCAM-1 or CD106). Activated microglia secrete a variety of inflammatory mediators including cytokines (TNF, and interleukins IL-1 $\beta$ and IL-6) and chemokines (macrophage inflammatory protein MIP-1 $\alpha$, monocyte chemoattractant protein MCP-1 and interferon (IFN) inducible protein IP-10) that promote the inflammatory state. The morphology of the cells changes from ramified to amoeboid as they take on a phagocytic role. These moderately active microglia are thought to perform 
beneficial functions, such as scavenging neurotoxins, removing dying cells and cellular debris, and secreting trophic factors that promote neuronal survival. Persistent activation of brain-resident microglia may increase the permeability of the $\mathrm{BBB}$ and promote increased infiltration of peripheral macrophages, the phenotype of which is critically determined by the CNS environment [10].

Microglia are the critical convergence point for the many diverse triggers that elicit an adaptive immune response (Figure 1). Stroke, hypoxia, and trauma compromise neuronal survival and indirectly trigger neuroinflammation as microglia become activated in response to the insult in an attempt to limit further injury. Infectious agents activate microglia either through damage to infected cells or direct recognition of foreign (viral or bacterial) proteins. Following exposure to neurotoxins such as the mitochondrial complex I inhibitor 1-methyl-4-phenyl-1,2,3,6-tetrahydropyridine (MPTP), the dopamine analog 6-hydroxydopamine (6-OHDA), or the pesticide paraquat, microglia become activated and primed. Microglial responses to these toxins may contribute to neuronal dysfunction and eventually hasten neurodegeneration (Czlonkowska et al., 1996; Kohutnicka et al., 1998; Liberatore et al., 1999; Dehmer et al., 2000; Vila et al., 2001). In addition, genetic mutations that give rise to increased production of toxic oligomeric, aggregated/truncated, or oxidized protein species promote sustained activation of microglia and may prime the immune system for aberrant responses to subsequent insults. Regardless of the initiating factor, all of these external or internal stimuli have the potential to trigger a self-perpetuating inflammatory response that, if left unresolved, may contribute to death of vulnerable neuronal populations.

\section{Evidence of neuroinflammation and cytokine involvement in neurodegenerative diseases Alzheimer's Disease (AD)}

Although the etiology of sporadic $\mathrm{AD}$ in humans is unknown, mutations in Amyloid Precursor Protein (APP) or components of its processing machinery $(\beta$-secretase and $\gamma$-secretase) result in overproduction of $A \beta 1-40$ and 142 peptides and are sufficient to cause disease [11-17]. Over 20 years ago, microglia were reported to localize to amyloid plaques in $\mathrm{AD}$ brain [18] and since then, the association between neuroinflammation and AD has been extensively investigated [7,19-24] and reviewed $[19,25]$. Human microglia display an activated phenotype when they surround plaques [23] that includes upregulation of Human Leukocyte Antigen-DR (HLA-DR) [18]. In addition to producing cytokines and other pro-inflammatory mediators $[19,26]$, microglia have also been reported to exert toxicity on neurons that have been pre-exposed to low concentrations of $A \beta 42$ via a CD14-dependent process [27]. Although it is clear that not all microglia activa- tion is injurious to neurons, it is becoming widely accepted that a type of neurotoxic microglia phenotype has a central role in the pathophysiology of AD.

While microglia can become activated after exposure to fibrillary $A \beta$ in vitro and are capable of phagocytosing it in vitro [28-30], it has been reported that in the presence of inflammatory cytokines or certain extracellular matrix proteins, microglia cannot phagocytize A $\beta$ [31]. This observation has been used to support the idea that the persistence and accumulation of amyloid plaques in vivo may be a direct result of this inhibitory behavior exerted by neuroinflammation. Moreover, numbers of IL- $1 \alpha$ positive (i.e., pro-inflammatory) microglia are increased in the cortical layers affected by plaque pathology in $\mathrm{AD}$ patients [32]. Since microglia are found in large numbers around neuritic amyloid plaques, but not diffuse in human $\mathrm{AD}$ patients, and in mice transgenic for mutant APP [33], it has been postulated that microglia play a role in the conversion of diffuse to neuritic senile plaques but not in the origin of diffuse plaques [34]. Specifically, postmortem analyses of microglia density in the neocortex of three groups of nondemented individuals at different stages of senile plaque formation versus $\mathrm{AD}$ patients revealed that the mean density of microglia was highest in the $\mathrm{AD}$ group and that microglia were associated with neuritic plaques much more often than with diffuse plaques Interestingly, individuals with some neuritic plaques also had microglia within a greater proportion of their diffuse plaques than individuals who only had diffuse plaques. While these findings raise the possibility that microglial activity may promote conversion of diffuse plaques into neuritic plaques, an important caveat of this study is that this conclusion is based on correlative observations postmortem and were not derived from a dynamic in situ analysis of microglial activity around diffuse or neuritic plaques.

The pro-inflammatory effect of $\mathrm{A} \beta$ deposition in brain has been recapitulated in aged mice transgenic for a familial $\mathrm{AD}$ mutation of APP, in which astrocytes and microglia expressing Il-1 $\beta$, IL- 6 and TNF have been found surrounding amyloid plaques [35]. The bacterial endotoxin lipopolysaccharide (LPS), a powerful inducer of inflammatory responses [36], exacerbates the appearance and severity of $\mathrm{AD}$ pathology in the APPV717F transgenic mouse [37], the APPswe transgenic mouse [38], and the triple-transgenic (3xTgAD) mouse [39]. In addition, the Transforming Growth Factor- $\beta$ (TGF- $\beta$ ) cytokine family increases $A \beta$ accumulation in the cerebral blood vessels of mice transgenic for human APP and is upregulated in blood vessels of human patients with Cerebral Amyloid Angiopathy (CAA) [40]. Co-addition of TGF- $\beta 1,2$ and 3 isoforms with $A \beta$ causes increased $A \beta$ accumulation in organotypic hippocampal slices [41]. Together, these 


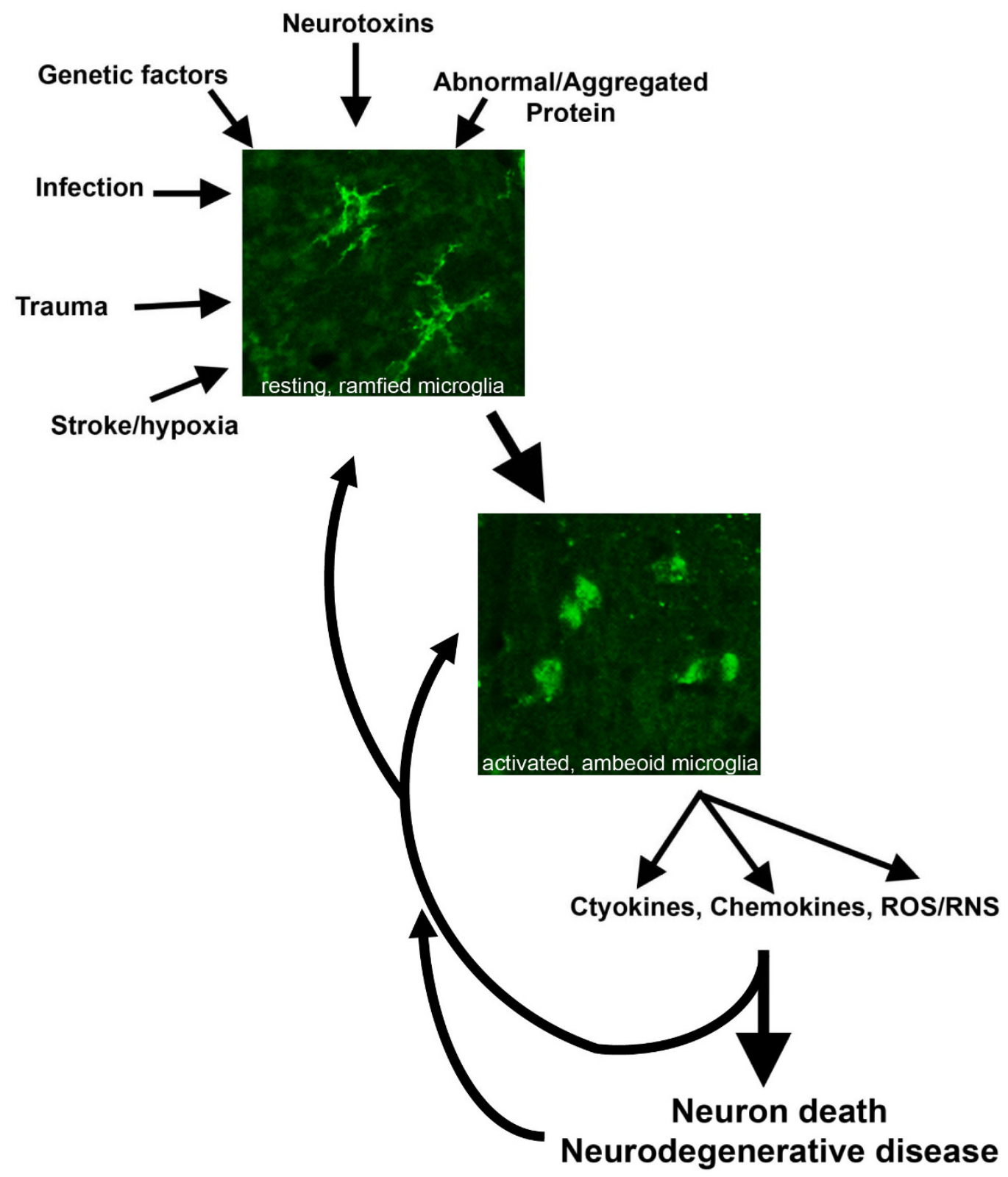

Figure I

Neuroinflammation can precede and contribute to neuronal dysfunction and degeneration. Divergent initiating triggers directly or indirectly converge to activate microglia (stained here with an antibody against F4/80) from a ramified/resting state to an ameboid-shape/activated state, initiating a self-propelling cycle of neuroinflammation and chronic over-production of inflammatory mediators. These mediators impact susceptible neuronal populations in the CNS and contribute to their demise within the context of each neurodegenerative disorder. The progressive loss of neurons that characterizes these disorders further contributes to generation of debris and keeps microglia activated indefinitely maintaining microglia in an activated state long-term. 
findings demonstrate the close association between microglia and plaque deposition and the ability of certain chronic inflammatory stimuli to exacerbate and accelerate amyloid-associated pathology. The emerging idea is that an inflamed CNS environment may influence the ability of microglia to contribute to plaque deposition rather than plaque removal, strongly suggesting that the microenvironment of the brain can influence whether microglia perform beneficial or deleterious functions in pathophysiological states.

While the role of inflammatory responses in $\mathrm{AD}$ are just beginning to be understood, there is little dispute that inflammatory mediators may represent both potentially useful biomarkers and targets for drug development. Cyclooxygenase 2 (COX2), a pro-inflammatory protein that is one of the targets of non-steroidal anti-inflammatory drugs (NSAIDs), and its homolog COX-1 [42], are elevated in AD brains [43]. Serum levels of the acute phase protein $\alpha 1$-antichymotrypsin, which is upregulated by injury, trauma and infection, are also significantly higher in $\mathrm{AD}$ patients than healthy controls [44]. And clinically, a proteomic study of plasma from control subjects, patients with Mild Cognitive Impairment (MCI) and patients with $\mathrm{AD}$ suggested that dysregulated systemic immune responses are present in patients who progress from $\mathrm{MCI}$ and go on to develop $\mathrm{AD}$, raising the interesting possibility that this inflammation "communicome" may serve as signature for early detection of the disease [45].

Not only is neuroinflammation believed to be one of the earliest consequences of $A \beta$ deposition, it has been shown to accelerate neurodegeneration and contribute to progression of pathology [46]. Epidemiological studies suggest a link between chronic use of non-steroidal antiinflammatory drugs (NSAIDs) and reduced risk for AD. In a study of siblings who all eventually developed AD, regular use of NSAIDs delayed the onset of AD and reduced the risk of AD with each year of use [47]. Participants in the Baltimore Longitudinal Aging Study also exhibited a reduced risk for $\mathrm{AD}$ with the use of NSAIDs, with those patients who had taken NSAIDs for more than 2 years showing the most reduction in AD risk [48]. Comparison of brains of aged but cognitively normal patients who used NSAIDs chronically with that of cognitively normal patients who did not use NSAIDs revealed no changes in the appearance of senile plaques, but a 3-fold decrease in the number of activated microglia in the brains of chronic NSAID users [49]. Most recently in what is the largest and longest duration epidemiological study to date, long-term (> 5 yrs) NSAID use, in particular ibuprofen, was shown to be protective against development of $\mathrm{AD}$ [50]. These findings suggest that the protection afforded by chronic NSAID use in the studies of AD patients may in part be derived by attenuation of microglia activation. Consistent with the epidemiological findings on ibuprofen, chronic ibuprofen administration in aged transgenic mice reduced the number and area of amyloid plaques, as well as the numbers of activated microglia [51], and administration of R-flurbiprofen rescued deficits in hippocampal and medial temporal lobe-dependent memory and learning [52]. However, thus far, clinical trials using systemic administration of NSAIDs have yielded mixed or inconclusive results [53-55], reflecting the need to identify and target the key inflammatory mediators that promote amyloid-associated neuropathology.

However, it is important to note that the presence inflammatory responses may also be necessary to prevent amyloid-associated neurotoxicity. For example, the activation of complement factor $\mathrm{C} 3$, the central component of the complement system and a key inflammatory protein may be necessary for plaque clearance by microglia in the ADafflicted brain $[56,57]$. In addition, an important component of any inflammatory response is the activation of anti-inflammatory loops that serve to limit and resolve the initial inflammatory response. The Peroxisome Proliferator-Activated Receptor- $\gamma$ (PPAR $\gamma$ ), a nuclear receptor which is activated by metabolites of prostaglandins generated by the COX enzymes and by certain NSAIDs, is upregulated in concert with the COX enzymes in AD brain [42]. As such, PPAR $\gamma$ activation exerts an anti-inflammatory effect, and PPAR $\gamma$ agonists have been shown to inhibit the production of cytokines and pro-inflammatory mediators in response to $A \beta$ [58]. In addition, there appears to be a feedback signaling loop between $A \beta$ and IL-1 $\beta$ : A $\beta$ can induce the production of IL-1 $\beta$ [7], and the presence of IL-1 $\beta$ greatly increases the secretion of cytokines IL- 6 and IL- 8 in response to A $\beta$ by astrocytes; in the other direction, IL- $1 \alpha$ and IL- $1 \beta$ both upregulate the expression of APP, thus probably upregulating the production of $A \beta$ [59]. The ratio of the pro-inflammatory cytokine IL- $1 \beta$ to the anti-inflammatory cytokine IL-10 is drastically elevated in the serum of AD patients, giving these patients a definite pro-inflammatory profile [60]. Increases in levels of IL-1 $\beta$ have been correlated with decreases in LTP in the hippocampus, showing that the cytokine itself may impair memory [61]. Other evidence, however, suggests that IL- $1 \beta$ may not be driving AD pathogenic processes. For example, functional inhibition of IL$1 \beta$ signaling in mice by genetic ablation of the IL1 receptor [62] or by infusion of IL-1 ra did not modulate $A \beta$ deposition. In addition, IL-1 $\beta$ was recently shown to upregulate the $\alpha$-secretase TACE, thus increasing nonamyloidogenic cleavage of APP and decreasing A $\beta$ production [63]. Therefore, while it may participate in neuroinflammatory responses in $\mathrm{AD}$ brain by activating microglia to secrete other inflammatory mediators, IL- $1 \beta$ is not required to drive $A \beta$ deposition and may in fact activate non-amyloidogenic pathways. 
An interesting approach to treating amyloid pathology in $\mathrm{AD}$ has been the active or passive immunization against $A \beta$. Immunizing PDAPP mice with A $\beta 42$ prevented or reduced the progression of $\mathrm{AD}$ pathology in these mice, depending on whether the immunization took place before or after the development of plaque pathology [64]. Vaccination with $A \beta$ peptides also ameliorated cognitive deficits in mice transgenic for a familial AD (FAD) mutation in APP and an FAD mutation in PS1 [65]. As an alternative delivery route, intranasal administration of $A \beta$ peptides reduced amyloid deposition in AD mouse models $[66,67]$. A $\beta$ vaccinations were also found successful in reducing $A \beta$ levels in two non-human primates, the rhesus monkey [68] and the Caribbean vervet [69]. A clinical trial of $A \beta 42$ vaccinations was undertaken by Elan Pharmaceuticals in $\mathrm{AD}$ patients, and the immunizations resulted in significant clearance of $A \beta$ and plaque removal in some of the patients $[70,71]$, as well as a slowing of the cognitive decline in patients who produced antibodies against the peptide [72]. Unfortunately, the immunization also resulted in dangerous T-lymphocyte meningoencephalitis in some patients, causing the arrest of these trials [70,73]. Passive immunization of PDAPP mice peripherally infused with antibodies that recognize aggregated $A \beta$ in neuritic plaques rapidly increased microglial clustering around plaques detectable by in vivo multiphoton microscopy [74] and reduced plaque burden and AD pathology in PDAPP mice [75]. Administration of antibodies specifically directed against oligomers of $A \beta$ improved learning and memory in Tg2576 mice [76]. Therefore, passive immunization may be a safer approach in $\mathrm{AD}$ patients. In addition, there is strong evidence that using shorter $A \beta$ peptides is safer than using full-length $A \beta 40$ or 42 as the immunogen [77]. In short, $A \beta$ immunotherapy holds promise but will need to be made safer and more effective in its ability to generate good antibody titers in the elderly [78]. If these novel immunogens can enhance $A \beta$ antibody generation without the adverse events seen in the earlier clinical trial, neuroimmune modulation by vaccination may become an effective way to prevent $\mathrm{AD}$.

\section{Parkinson's Disease (PD)}

Classically, the neuropathological hallmark of idiopathic PD includes the presence of $\alpha$-synuclein-positive inclusions in the cell body (Lewy bodies) and processes (Lewy neurites) of specific neurons of the brainstem and a classic motor phenotype resulting from substantial loss of dopaminergic neurons from the substantia nigra pars compacta (SNpc) (reviewed in [79]). A number of studies have confirmed the presence of inflammatory mediators (including TNF, IL-1 $\beta$, IL-6, and IFN $\gamma$ ) in the cerebrospinal fluid (CSF) of patients with PD as well as in the postmortem SNpc in PD patient brains [80-84]. Significantly elevated levels of TNF mRNA and protein can be detected in the rodent midbrain substantia nigra within hours of in vivo administration of two neurotoxins widely used to model parkinsonism in rodents, 6-hydroxydopamine (6OHDA) [8] and 1-methyl-4-phenyl-1,2,3,6-tetrahydropyridine (MPTP) [85-87]. Consistent with a role of TNF in contributing to dopaminergic neuron death in chronic parkinsonism, plasma TNF levels were shown to remain elevated in MPTP-treated non-human primates one year after administration of the neurotoxin [88]. In contrast, studies involving mice deficient in TNF or both TNF receptors have yielded conflicting results in that one group reported lack of TNF receptors altered dopamine metabolism and reduced survival of dopaminergic terminals [86] and other groups reported TNF-deficient mice to have reduced sensitivity to MPTP-induced neurotoxicity $[85,87]$. Loss of TNF receptors versus TNF ligand during development might alter the behavior of microglia or other immune cell populations and contribute to conflicting outcomes in these studies. In addition, the use of different MPTP lesioning regimens in these two studies make it difficult to compare them directly.

Additional evidence that inflammation (and in particular $\mathrm{TNF}$ ) is involved in nigral DA neuron degeneration comes from two endotoxin rat models. In the first model chronic low dose lipopolysaccharide (LPS) infusion into SNpc of rats results in delayed, selective and progressive loss of nigral DA neurons [89]. In the second model exposure of pregnant rats to LPS and thus, in utero exposure of embryos to the endotoxin, caused a loss of DA neurons in postnatal brains [90]. Most importantly, chronic infusion of dominant negative TNF inhibitor proteins into SNpc of adult rats protected nigral DA neurons from LPS and 6OHDA induced degeneration [91] as did a single nigral injection of a lentivirus encoding DN-TNF in 6-OHDA hemiparkinsonian rats [92]. Given that TNF receptors are expressed in nigrostriatal dopamine neurons $[93,94]$ and these neurons are selectively vulnerable to TNF-induced toxicity [95-99], these early genetic studies and the more recent chronic inflammation models of PD strongly implicate TNF and its downstream targets in neurotoxinand endotoxin-induced loss of nigral DA neurons. However, because it is clear that the permeability of the BBB increases with age increases the likelihood of peripheral immune cell infiltration into the CNS, TNF produced by brain-resident microglia may not be acting alone in mediating DA neuron cell death but in concert with other circulating neurotoxic factors to increase the inflammatory susceptibility of nigral DA neurons and development of PD.

Another link between inflammation and neurodegeneration comes from studies of single nucleotide polymorphisms that are associated with over-production of cytokines, chemokines and acute phase proteins. These 
polymorphisms are over-represented in specific cohorts of individuals affected with PD and may confer increased susceptibility for the disease [100-104]. However, most of these findings have not been replicated in independent studies and a meta-analysis of multiple association studies is needed to assess the overall genetic effect of cytokine gene polymorphisms on neurodegenerative disease. Lastly, the advent of technologies such as positron emission tomography (PET) brain scans has enabled clinicians to image microglial activation in living patients. Recent PET studies confirm that patients with idiopathic PD have markedly elevated microglia activation in the pons, basal ganglia, striatum, and frontal and temporal cortical regions irrespective of the number of years with the disease compared to healthy age-matched controls [81]. Persistent activation of the abundant number of microglia in the midbrain region are likely the direct result of elevated levels of cytokines acting in an autocrine manner to potentiate inflammatory responses (e.g., auto-amplification of reactive oxygen species, nitric oxide, and superoxide radicals to form highly oxidizing peroxynitrite species) $[7,105-108]$. Given that DA neurons in the midbrain have an inherently elevated oxidative intracellular environment as a result of oxidation reactions required for the synthesis of the neurotransmitter dopamine, chronic neuroinflammation is likely to further enhance oxidative stress, hasten dysfunction, and eventually lead to death of DA neurons.

\section{Huntington's Disease (HD)}

Huntington's disease (HD) is an autosomal dominant neurodegenerative disorder that has been linked to mutations in the huntingtin gene (htt) [109]. CAG repeat expansions in the htt gene result in an increased number of glutamine residues in the huntingtin protein (polyglutamine expansion). Mutant htt causes degeneration of neurons, predominately in the caudate putamen and cortex, causing HD patients to suffer from uncontrolled movements, emotional disturbances and dementia. While the mechanism by which mutant htt causes neurodegeneration remains obscure, evidence supporting inflammation as an important player in HD is accumulating.

Recent studies have demonstrated that inflammation appears both peripherally and in the central nervous system (CNS) during the progression of HD and HD-like pathology. The R6/2 mouse model of HD displays increased serum levels of IL- 6 and in downstream IL-6 effectors, such as alpha-2-macroglobulin (A2 M) and complement components [110]. In the CNS, microarray profiling of several brain regions from HD patients and controls revealed increased gliosis and expression of inflammation-related genes, including GFAP and complement proteins. Increases were most pronounced in the caudate putamen where brain pathology is most severe in
HD patients [111]. Increases in labeling of complement proteins in neurons and astrocytes and a 2-5 fold increase in activators and regulators of the classical complement pathway have also been detected in human HD brains by RT-PCR [112]. Lastly, clinical plasma samples from HD gene carriers contain increased levels of pro-inflammatory cytokines involved in the innate immune response, such as IL-6 [113].

A number of studies indicate that the altered immune profile in HD occurs before onset of clinical HD symptoms, suggesting that striatal and cortical neurodegeneration could be exacerbated by inflammation. For example, plasma samples from HD gene carriers contain increased levels of pro-inflammatory cytokines involved in the innate immune response before the onset of clinical symptoms and investigators have been able to discriminate controls from presymptomatic HD mutation carriers by measuring the levels of 3 cytokines, IL-5, IL- 6 , and IL10 in plasma [113]. In brains of mutant htt carriers, microglia are activated before onset of symptoms and increased microglial activation correlates with an increased chance of developing HD symptoms in 5 years [114]. Once symptoms have manifested, microglial activation correlates with disease severity $[115,116]$. In the $3-$ nitroproprionic acid neurotoxin model of HD in rats, treatment with Celastrol, an anti-inflammatory and antioxidant compound derived from plants, reduced striatal lesion volume [117], indicating that controlling an inflammatory response could be therapeutically beneficial as HD progresses. However, treatment with acetylsalicylate or rofecoxib, anti-inflammatory drugs commonly used in the clinic, was not neuroprotective in either the R6/2 or N171-82Q transgenic mouse models of HD [118].

Since mutant htt is known to cause a number of deleterious effects in cells, it is possible that increased inflammation in HD brains is simply the CNS response to neuronal death that is a direct result of mutant htt toxicity. However, several studies point to the intriguing possibility that mutant htt might itself trigger an inflammatory response, the by-products of which could cause degeneration of neurons. For example, inflammation in HD could be a result of overactive immune cells, such as macrophages in the periphery and microglia in the CNS. Monocytes from HD patients secrete abnormally high levels of the proinflammatory cytokine IL- 6 in response to a combination of interferon-gamma (IFN- $\gamma$ ) and LPS. Microglia from YAC128 and R6/2 mouse models of HD respond in a similar overactive manner [113]. Mutant htt is found in glial nuclei where it can act to alter gene expression, probably because of its aberrant interactions with transcription factors that are made possible by glutamine expansionrelated conformational changes in the htt protein [119]. 
Interestingly, mutant, but not normal htt activates the IKK complex, the major kinase that leads to phosphorylationinduced degradation of IкBs, leading to increased translocation of NF- $\kappa \mathrm{B}$ dimers to the nucleus in mouse striatal cells [120]. Since NF-кB can promote expression of IL-6 and other inflammatory cytokines in glia, such an interaction provides a candidate mechanism by which mutant htt could alter the activity of immune cells leading to an abnormally robust inflammatory response.

The presence of increased inflammatory mediators in the periphery and in the CNS beg the question of whether CNS inflammation "leaks" into the periphery to alter the peripheral immune profile or whether inflammation is triggered in the periphery and immune modulators are allowed to cross the BBB to trigger or contribute to a central inflammatory response. Another possibility is that an inflammatory response is triggered in the periphery and the CNS by an analogous mechanism. These alternatives are just beginning to be explored.

\section{Amyotrophic Lateral Sclerosis (ALS)}

Amyotrophic lateral sclerosis (ALS) involves a progressive degeneration of motor neurons in the brain and spinal cord. While most cases are sporadic in origin, approximately $5-10 \%$ of the cases are caused by an autosomal dominant mutation. ALS is typically fatal within 5 years of diagnosis due to a progressive, generalized paralysis that eventually affects the muscles of respiration, causing respiratory failure. Areas where degenerating motor neurons are present in both ALS patients and mouse models are marked by the presence of cytokines and immune cells, including $\mathrm{T}$ cells, activated microglia, and astrocytes $[121,122]$. In addition PET imaging of ALS patients showed an increase in activated microglia in the motor cortex that correlates with upper motor neuron symptoms [123]. In some ALS disease models the presence of immune cells precedes the disease phenotype [124], and the chemokine MCP-1, a potent chemotactic stimulus for microglia [125] is elevated in the CSF of ALS patients [126], suggesting that neuroinflammation could contribute to disease progression. In addition, the levels of general markers of inflammation in the serum of ALS patients correlate positively with the severity of their disability [127]. While multiple genetic loci have been identified as causal in familial forms of ALS, $20 \%$ of familial cases involve a gain of function mutation in $\mathrm{Cu} / \mathrm{Zn}$ superoxide dismutase I (SOD1) [128]. In addition to the well-established role of SOD1 as a critical anti-oxidant enzyme, evidence suggests that part of its normal function is to protect against protein aggregation, a phenomenon that is known to hasten neuronal degeneration. Nevertheless, several studies have suggested that SOD1 mutations in neurons alone are insufficient to cause ALS and that dysfunction in support glia may contribute to disease development and progression [129-132]. For example, ablating microglial expression of mutant SOD 1 (mSOD1) or transplanting bone marrow from wild-type mice into mSOD1 transgenic mice increases the life span of mutant mice $[133,134]$, suggesting that SOD1 mutations may indirectly contribute to neuronal death by affecting glial rather than neuronal function. Consistent with this idea, mSOD1 mice stimulated with LPS secrete more inflammatory mediators, including TNF [135], MCP-1, TGF$\beta[121]$ and IFN- $\gamma[136]$, than control mice. Importantly, levels of TNF correlate with severity of motor neuron loss in mouse models of the disease $[137,138]$ and both TNF receptors are elevated in the serum of ALS patients [139].

In pre-clinical mouse models, certain anti-inflammatory treatments aimed at suppressing microglia activation have been shown to increase the life expectancy of mice expressing human mutant SOD1 by more than $30 \%$ [140]. Anti-inflammatory treatments also prevented neurotoxicity when the CSF of ALS patients was applied to rat spinal cord motor neurons [141]. Although a generalized neuroinflammatory response may be driving progressive loss of motor neurons, not all inflammatory mediators have been strongly implicated in ALS. For instance, IL-1 $\beta$ may not be critical to ALS pathogenesis as genetic deletion of IL- $1 \beta$ does not change the lifespan or rate of motor neurodegeneration in mSOD-1 mice [142].

\section{Summary and Conclusion}

It is becoming increasingly evident that neuroinflammation plays a crucial role in the development and progression of many neurodegenerative diseases. Glia and in particular microglia are central to mediating the effects of neuroinflammation. While neuroinflammation and microglia provide an attractive therapeutic target in the treatment and prevention of neurodegenerative diseases investigators face several challenges ahead (Appendix 2) which must be overcome before one can advocate in favor of large-scale anti-inflammatory trials in the clinic. Some of these include developing approaches to improve the access of drugs to CNS tissue as well as developing therapies that maintain or optimize the beneficial effects of neuroinflammation while eliminating or minimizing its detrimental effects.

\section{Competing interests}

The authors declare that they have no competing interests.

\section{Authors' contributions}

MGT: primary manuscript content, primary writing of Parkinson's disease, shared primary writing of overview, and secondary contributions to microglial activation and Alzheimer's disease. TCFC: primary writing of microglia activation, ALS, and conclusions, and shared primary writing of overview. LTA: primary writing of Huntington's 
disease, secondary contributions to Parkinson's and Alzheimer's disease sections. FEM: primary writing of Alzheimer's disease and secondary contributions to ALS section. All authors' contributed to editing and revision of manuscript and have read and approved the final manuscript.

\section{Appendix I: Key Observations}

1. Neurodegenerative diseases are associated with signs of chronic neuroinflammation

2. A variety of initiating triggers (some as yet unknown) associated with the different neurodegenerative disorders converge at a common intersection point - activation of microglia.

3. While the initial neuroimmune response may be aimed at limiting the disease process, chronic neuroinflammation driven by persistent microglia activation is likely to aid in the progression of the disease and the hastening of neuronal demise.

4. How the inflammatory response affects specific neuronal and glial populations and contributes to specific neurodegenerative diseases remains a critical and unanswered question.

\section{Appendix 2: Critical challenges involved in developing neuroprotective anti-inflammatory therapeutic strategies}

1. Identify internal and external factors that trigger chronic neuroinflammatory responses, with a focus on how acute immune responses become chronic.

\section{Identify inflammatory mediators that compromise sur-} vival of specific neuronal populations.

3. Develop therapeutic compounds that cross the blood brain barrier (BBB)

4. Selectively target destructive inflammatory mediators without compromising beneficial survival-promoting effects and overall immune function.

5. Develop inclusion and exclusion criteria for human subjects to be enrolled in clinical trials taking into account their immune status.

\section{References}

I. Rivest S: Regulation of innate immune responses in the brain. Nat Rev Immunol 2009, 9(6):429-39.

2. Crutcher KA, Gendelman HE, Kipnis J, Perez-Polo JR, Perry VH, Popovich PG, Weaver LC: Debate: "is increasing neuroinflammation beneficial for neural repair?". I Neuroimmune Pharmacol 2006, I(3): I95-2II.

3. Popovich PG, Longbrake EE: Can the immune system be harnessed to repair the CNS? Nat Rev Neurosci 2008, 9(6):48I-93.
4. Tansey MG, McCoy MK, Frank-Cannon TC: Neuroinflammatory mechanisms in Parkinson's disease: potential environmental triggers, pathways, and targets for early therapeutic intervention. Exp Neurol 2007, 208(I): I-25.

5. Block ML, Hong JS: Microglia and inflammation-mediated neurodegeneration: multiple triggers with a common mechanism. Prog Neurobiol 2005, 76(2):77-98.

6. McGeer EG, McGeer PL: The role of anti-inflammatory agents in Parkinson's disease. CNS Drugs 2007, 2 I(I 10):789-97.

7. Mrak RE, Griffin WS: Glia and their cytokines in progression of neurodegeneration. Neurobiol Aging 2005, 26(3):349-54.

8. Nagatsu T, Sawada M: Cellular and molecular mechanisms of Parkinson's disease: neurotoxins, causative genes, and inflammatory cytokines. Cell Mol Neurobiol 2006, 26(46):78I-802.

9. Tansey MG, Wyss-Coray T: Cytokines in CNS Inflammation and Disease. In Central Nervous System Diseases and Inflammation, T.E.C Edited by: Lane M, Bergmann C, Wyss-Coray T. Springer: New York; 2008:59-106.

10. Schmid CD, Melchior B, Masek K, Puntambekar SS, Danielson PE, Lo DD, Sutcliffe JG, Carson MJ: Differential gene expression in LPS/ IFNgamma activated microglia and macrophages: in vitro versus in vivo. I Neurochem 2009, 109(Suppl I): I 17-25.

II. Nee LE, Polinsky RJ, Eldridge R, Weingartner H, Smallberg S, Ebert M: A family with histologically confirmed Alzheimer's disease. Arch Neurol 1983, 40(4):203-8.

12. Goate A, Chartier-Harlin MC, Mullan M, Brown J, Crawford F, Fidani L, Giuffra L, Haynes A, Irving N, James L, Mant R, Newton P, Rooke $\mathrm{K}$, Roques $\mathrm{P}$, Talbot C, Pericak-Vance M, Roses A, Williamson R, Rossor $M$, Owen M, Hardy J: Segregation of a missense mutation in the amyloid precursor protein gene with familial Alzheimer's disease. Nature 199I, 349(63 I I):704-6.

13. Citron M, Oltersdorf T, Haass C, McConlogue L, Hung AY, Seubert P, Vigo-Pelfrey C, Lieberburg I, Selkoe DJ: Mutation of the betaamyloid precursor protein in familial Alzheimer's disease increases beta-protein production. Nature 1992, 360(6405):672-4.

14. Cai XD, Golde TE, Younkin SG: Release of excess amyloid beta protein from a mutant amyloid beta protein precursor. Science 1993, 259(5094):5।4-6.

15. Lopera F, Ardilla A, Martinez A, Madrigal L, Arango-Viana JC, Lemere CA, Arango-Lasprilla JC, Hincapie L, Arcos-Burgos M, Ossa JE, Behrens IM, Norton J, Lendon C, Goate AM, Ruiz-Linares A, Rosselli M, Kosik KS: Clinical features of early-onset Alzheimer disease in a large kindred with an E280A presenilin-I mutation. JAMA 1997, 277(10):793-9.

16. Lemere CA, Lopera F, Kosik KS, Lendon CL, Ossa J, Saido TC, Yamaguchi H, Ruiz A, Martinez A, Madrigal L, Hincapie L, Arango JC, Anthony DC, Koo EH, Goate AM, Selkoe DJ: The E280A presenilin I Alzheimer mutation produces increased A beta 42 deposition and severe cerebellar pathology. Nat Med 1996, 2(I0): I I 46-50.

17. Whalen BM, Selkoe DJ, Hartley DM: Small non-fibrillar assemblies of amyloid beta-protein bearing the Arctic mutation induce rapid neuritic degeneration. Neurobiol Dis 2005, 20(2):254-66.

18. McGeer PL, Itagaki S, Tago H, McGeer EG: Reactive microglia in patients with senile dementia of the Alzheimer type are positive for the histocompatibility glycoprotein HLA-DR. Neurosci Lett 1987, 79(1-2): 195-200.

19. Akiyama H, Barger S, Barnum S, Bradt B, Bauer J, Cole GM, Cooper NR, Eikelenboom P, Emmerling M, Fiebich BL, Finch CE, Frautschy S, Griffin WS, Hampel H, Hull M, Landreth G, Lue L, Mrak R, Mackenzie IR, McGeer PL, O'Banion MK, Pachter J, Pasinetti G, Plata-Salaman C, Rogers J, Rydel R, Shen Y, Streit W, Strohmeyer R, Tooyoma I, Van Muiswinkel FL, Veerhuis R, Walker D, Webster S, Wegrzyniak B, Wenk G, Wyss-Coray T: Inflammation and Alzheimer's disease. Neurobiol Aging 2000, 2 I (3):383-42I.

20. Eikelenboom P, Veerhuis R, Scheper W, Rozemuller AJ, van Gool WA, Hoozemans J]: The significance of neuroinflammation in understanding Alzheimer's disease. J Neural Transm 2006, II3(II):1685-95.

21. Griffin WS: Inflammation and neurodegenerative diseases. Am J Clin Nutr 2006, 83(2):470S-474S. 
22. Hoozemans J], Veerhuis R, Rozemuller JM, Eikelenboom P: Neuroinflammation and regeneration in the early stages of Alzheimer's disease pathology. Int J Dev Neurosci 2006, 24(2-3): I 57-65.

23. McGeer EG, McGeer PL: Inflammatory processes in Alzheimer's disease. Prog Neuropsychopharmacol Biol Psychiatry 2003, 27(5):74l-9.

24. Wyss-Coray T, Mucke L: Inflammation in neurodegenerative disease--a double-edged sword. Neuron 2002, 35(3):419-32.

25. McAlpine FE, Lee JK, Harms AS, Ruhn KA, Blurton-Jones M, Hong J, Das P, Golde TE, LaFerla FM, Oddo S, Blesch A, Tansey MG: Inhibition of soluble TNF signaling in a mouse model of Alzheimer's disease prevents pre-plaque amyloid-associated neuropathology. Neurobiol Dis 2009, 34(I): I63-77.

26. Eikelenboom P, Bate C, Van Gool WA, Hoozemans JJ, Rozemuller JM, Veerhuis R, Williams A: Neuroinflammation in Alzheimer's disease and prion disease. Glia 2002, 40(2):232-9.

27. Bate C, Veerhuis R, Eikelenboom P, Williams A: Microglia kill amyloid-beta I-42 damaged neurons by a CD I 4-dependent process. Neuroreport 2004, I 5(9): |427-30.

28. Ard MD, Cole GM, Wei J, Mehrle AP, Fratkin JD: Scavenging of Alzheimer's amyloid beta-protein by microglia in culture. J Neurosci Res 1996, 43(2): 190-202.

29. Kopec KK, Carroll RT: Alzheimer's beta-amyloid peptide I-42 induces a phagocytic response in murine microglia. J Neurochem I998, 7I(5):2 I23-3I.

30. Shaffer LM, Dority MD, Gupta-Bansal R, Frederickson RC, Younkin SG, Brunden KR: Amyloid beta protein (A beta) removal by neuroglial cells in culture. Neurobiol Aging 1995, I 6(5):737-45.

31. Koenigsknecht-Talboo J, Landreth GE: Microglial phagocytosis induced by fibrillar beta-amyloid and IgGs are differentially regulated by proinflammatory cytokines. I Neurosci 2005, 25(36):8240-9.

32. Sheng JG, Griffin WS, Royston MC, Mrak RE: Distribution of interleukin-I-immunoreactive microglia in cerebral cortical layers: implications for neuritic plaque formation in Alzheimer's disease. Neuropathol Appl Neurobiol 1998, 24(4):278-83

33. Frautschy SA, Yang F, Irrizarry M, Hyman B, Saido TC, Hsiao K, Cole GM: Microglial response to amyloid plaques in APPsw transgenic mice. Am J Pathol 1998, I 52(I):307-I7.

34. Mackenzie IR, Hao C, Munoz DG: Role of microglia in senile plaque formation. Neurobiol Aging 1995, I6(5):797-804.

35. Benzing WC, Wujek JR, Ward EK, Shaffer D, Ashe KH, Younkin SG, Brunden KR: Evidence for glial-mediated inflammation in aged APP(SW) transgenic mice. Neurobiol Aging 1999, 20(6):58I-9.

36. Flick DA, Gifford GE: Production of tumor necrosis factor in unprimed mice: mechanism of endotoxin-mediated tumor necrosis. Immunobiology I 986, I 7 I (4-5):320-8.

37. Qiao X, Cummins DJ, Paul SM: Neuroinflammation-induced acceleration of amyloid deposition in the APPV7I7F transgenic mouse. Eur J Neurosci 200I, I 4(3):474-82.

38. Sheng JG, Bora SH, Xu G, Borchelt DR, Price DL, Koliatsos VE: Lipopolysaccharide-induced-neuroinflammation increases intracellular accumulation of amyloid precursor protein and amyloid beta peptide in APPswe transgenic mice. Neurobiol Dis 2003, I 4(I): I33-45.

39. Kitazawa M, Oddo S, Yamasaki TR, Green KN, LaFerla FM: Lipopolysaccharide-induced inflammation exacerbates tau pathology by a cyclin-dependent kinase 5-mediated pathway in a transgenic model of Alzheimer's disease. J Neurosci 2005, 25(39):8843-53.

40. Wyss-Coray T, Masliah E, Mallory M, McConlogue L, Johnson-Wood $\mathrm{K}$, Lin C, Mucke L: Amyloidogenic role of cytokine TGF-beta I in transgenic mice and in Alzheimer's disease. Nature 1997, 389(665I):603-6.

4I. Harris-White ME, Chu T, Balverde Z, Sigel Jl, Flanders KC, Frautschy SA: Effects of transforming growth factor-beta (isoforms I-3) on amyloid-beta deposition, inflammation, and cell targeting in organotypic hippocampal slice cultures. J Neurosci 1998, I 8(24): I 0366-74.

42. Kitamura $Y$, Shimohama S, Koike H, Kakimura J, Matsuoka Y, Nomura Y, Gebicke-Haerter PJ, Taniguchi T: Increased expression of cyclooxygenases and peroxisome proliferator-activated receptor-gamma in Alzheimer's disease brains. Biochem Biophys Res Commun 1999, 254(3):582-6.
43. Lukiw W], Bazan NG: Neuroinflammatory signaling upregulation in Alzheimer's disease. Neurochem Res 2000, 25(9I0): I I73-84.

44. Lieberman J, Schleissner L, Tachiki KH, Kling AS: Serum alpha Iantichymotrypsin level as a marker for Alzheimer-type dementia. Neurobiol Aging 1995, I 6(5):747-53.

45. Ray S, Britschgi M, Herbert C, Takeda-Uchimura Y, Boxer A, Blennow K, Friedman LF, Galasko DR, Jutel M, Karydas A, Kaye JA, Leszek J, Miller BL, Minthon L, Quinn JF, Rabinovici GD, Robinson WH, Sabbagh MN, So YT, Sparks DL, Tabaton M, Tinklenberg J, Yesavage JA, Tibshirani R, Wyss-Coray $\mathrm{T}$ : Classification and prediction of clinical Alzheimer's diagnosis based on plasma signaling proteins. Nat Med 2007, I3(I I): I359-62.

46. Craft JM, Watterson DM, Van Eldik LJ: Human amyloid betainduced neuroinflammation is an early event in neurodegeneration. Glia 2006, 53(5):484-90.

47. Breitner JC, Welsh KA, Helms MJ, Gaskell PC, Gau BA, Roses AD, Pericak-Vance MA, Saunders AM: Delayed onset of Alzheimer's disease with nonsteroidal anti-inflammatory and histamine H2 blocking drugs. Neurobiol Aging 1995, I 6(4):523-30.

48. Stewart WF, Kawas C, Corrada M, Metter EJ: Risk of Alzheimer's disease and duration of NSAID use. Neurology 1997, 48(3):626-32

49. Mackenzie IR, Munoz DG: Nonsteroidal anti-inflammatory drug use and Alzheimer-type pathology in aging. Neurology 1998 , 50(4):986-90.

50. Vlad SC, Miller DR, Kowall NW, Felson DT: Protective effects of NSAIDs on the development of Alzheimer disease. Neurology 2008, 70( I 9): I672-7.

5I. Lim GP, Yang F, Chu T, Chen P, Beech W, Teter B, Tran T, Ubeda O, Ashe $\mathrm{KH}$, Frautschy SA, Cole GM: Ibuprofen suppresses plaque pathology and inflammation in a mouse model for Alzheimer's disease. J Neurosci 2000, 20(15):5709-14.

52. Kukar T, Prescott S, Eriksen JL, Holloway V, Murphy MP, Koo EH, Golde TE, Nicolle MM: Chronic administration of R-flurbiprofen attenuates learning impairments in transgenic amyloid precursor protein mice. BMC Neurosci 2007, 8:54.

53. Launer L: Nonsteroidal anti-inflammatory drug use and the risk for Alzheimer's disease: dissecting the epidemiological evidence. Drugs 2003, 63(8):731-9.

54. McGeer PL, McGeer EG: NSAIDs and Alzheimer disease: epidemiological, animal model and clinical studies. Neurobiol Aging 2007, 28(5):639-47.

55. van Gool WA, Aisen PS, Eikelenboom P: Anti-inflammatory therapy in Alzheimer's disease: is hope still alive? J Neurol 2003, 250(7):788-92.

56. Maier M, Peng $Y$, Jiang L, Seabrook TJ, Carroll MC, Lemere CA: Complement $\mathrm{C} 3$ deficiency leads to accelerated amyloid beta plaque deposition and neurodegeneration and modulation of the microglia/macrophage phenotype in amyloid precursor protein transgenic mice. J Neurosci 2008 , 28(25):6333-4I.

57. Wyss-Coray T, Yan F, Lin AH, Lambris JD, Alexander J], Quigg RJ, Masliah E: Prominent neurodegeneration and increased plaque formation in complement-inhibited Alzheimer's mice. Proc Natl Acad Sci USA 2002, 99(16): 10837-42.

58. Combs CK, Johnson DE, Karlo JC, Cannady SB, Landreth GE: Inflammatory mechanisms in Alzheimer's disease: inhibition of beta-amyloid-stimulated proinflammatory responses and neurotoxicity by PPARgamma agonists. J Neurosci 2000, 20(2):558-67.

59. Sheng JG, Ito K, Skinner RD, Mrak RE, Rovnaghi CR, Van Eldik LJ, Griffin WS: In vivo and in vitro evidence supporting a role for the inflammatory cytokine interleukin-I as a driving force in Alzheimer pathogenesis. Neurobiol Aging 1996, I 7(5):76I-6.

60. Remarque EJ, Bollen EL, Weverling-Rijnsburger AW, Laterveer JC, Blauw G], Westendorp RG: Patients with Alzheimer's disease display a pro-inflammatory phenotype. Exp Gerontol 200I, 36(I): $171-6$.

61. Lynch MA: Age-related impairment in long-term potentiation in hippocampus: a role for the cytokine, interleukin-I beta? Prog Neurobiol 1998, 56(5):57|-89.

62. Das P, Smithson LA, Price RW, Holloway VM, Levites Y, Chakrabarty $P$, Golde TE: Interleukin-I receptor I knockout has no effect on amyloid deposition in $\mathrm{Tg} 2576$ mice and does not alter effi- 
cacy following Abeta immunotherapy. I Neuroinflammation 2006, 3:17.

63. Tachida $Y$, Nakagawa K, Saito T, Saido TC, Honda T, Saito $Y$, Murayama S, Endo T, Sakaguchi G, Kato A, Kitazume S, Hashimoto Y: Interleukin-I beta up-regulates TACE to enhance alphacleavage of APP in neurons: resulting decrease in Abeta production. J Neurochem 2008, 104(5): I387-93.

64. Schenk D, Barbour R, Dunn W, Gordon G, Grajeda H, Guido T, Hu K, Huang J, Johnson-Wood K, Khan K, Kholodenko D, Lee M, Liao Z, Lieberburg I, Motter R, Mutter L, Soriano F, Shopp G, Vasquez N, Vandevert C, Walker S, Wogulis M, Yednock T, Games D, Seubert P: Immunization with amyloid-beta attenuates Alzheimer-disease-like pathology in the PDAPP mouse. Nature 1999, 400(6740): $173-7$.

65. Morgan D, Diamond DM, Gottschall PE, Ugen KE, Dickey C, Hardy J, Duff K, Jantzen P, DiCarlo G, Wilcock D, Connor K, Hatcher J, Hope C, Gordon M, Arendash GW: A beta peptide vaccination prevents memory loss in an animal model of Alzheimer's disease. Nature 2000, 408(6815):982-5.

66. Lemere CA, Maron R, Selkoe DJ, Weiner HL: Nasal vaccination with beta-amyloid peptide for the treatment of Alzheimer's disease. DNA Cell Biol 200I, 20(II):705-II

67. Lemere CA, Spooner ET, Leverone JF, Mori C, Clements JD: Intranasal immunotherapy for the treatment of Alzheimer's disease: Escherichia coli LT and LT(RI92G) as mucosal adjuvants. Neurobiol Aging 2002, 23(6):991-1000.

68. Gandy S, DeMattos RB, Lemere CA, Heppner FL, Leverone J, Aguzzi A, Ershler WB, Dai J, Fraser P, St George Hyslop P, Holtzman DM, Walker LC, Keller ET: Alzheimer's Abeta vaccination of rhesus monkeys (Macaca mulatta). Mech Ageing Dev 2004, | 25(2): |49-5|.

69. Lemere CA, Beierschmitt A, Iglesias M, Spooner ET, Bloom JK, Leverone JF, Zheng JB, Seabrook TJ, Louard D, Li D, Selkoe DJ, Palmour RM, Ervin FR: Alzheimer's disease abeta vaccine reduces central nervous system abeta levels in a non-human primate, the Caribbean vervet. Am J Pathol 2004, 165(I):283-97.

70. Nicoll JA, Barton E, Boche D, Neal JW, Ferrer I, Thompson P, Vlachouli C, Wilkinson D, Bayer A, Games D, Seubert P, Schenk D, Holmes C: Abeta species removal after abeta42 immunization. J Neuropathol Exp Neurol 2006, 65(I I):1040-8.

7I. Nicoll JA, Wilkinson D, Holmes C, Steart P, Markham H, Weller RO: Neuropathology of human Alzheimer disease after immunization with amyloid-beta peptide: a case report. Nat Med 2003, 9(4):448-52.

72. Hock C, Konietzko U, Streffer JR, Tracy J, Signorell A, Muller-Tillmanns B, Lemke U, Henke K, Moritz E, Garcia E, Wollmer MA, Umbricht D, de Quervain DJ, Hofmann M, Maddalena A, Papassotiropoulos A, Nitsch RM: Antibodies against beta-amyloid slow cognitive decline in Alzheimer's disease. Neuron 2003, 38(4):547-54.

73. Orgogozo JM, Gilman S, Dartigues JF, Laurent B, Puel M, Kirby LC, Jouanny P, Dubois B, Eisner L, Flitman S, Michel BF, Boada M, Frank $A$, Hock C: Subacute meningoencephalitis in a subset of patients with AD after Abeta42 immunization. Neurology 2003, 6 I (I):46-54.

74. Koenigsknecht-Talboo J, Meyer-Luehmann M, Parsadanian M, GarciaAlloza M, Finn MB, Hyman BT, Bacskai BJ, Holtzman DM: Rapid microglial response around amyloid pathology after systemic anti-Abeta antibody administration in PDAPP mice. J Neurosci 2008, 28(52): 14156-64.

75. Bard F, Cannon C, Barbour R, Burke RL, Games D, Grajeda H, Guido T, Hu K, Huang J, Johnson-Wood K, Khan K, Kholodenko D, Lee M, Lieberburg I, Motter R, Nguyen M, Soriano F, Vasquez N, Weiss K, Welch $B$, Seubert $P$, Schenk D, Yednock T: Peripherally administered antibodies against amyloid beta-peptide enter the central nervous system and reduce pathology in a mouse model of Alzheimer disease. Nat Med 2000, 6(8):916-9.

76. Lee EB, Leng LZ, Zhang B, Kwong L, Trojanowski JQ, Abel T, Lee VM: Targeting amyloid-beta peptide (Abeta) oligomers by passive immunization with a conformation-selective monoclonal antibody improves learning and memory in Abeta precursor protein (APP) transgenic mice. J Biol Chem 2006, 28 I (7):4292-9.

77. Lemere CA, Maier M, Peng Y, Jiang L, Seabrook TJ: Novel Abeta immunogens: is shorter better? Curr Alzheimer Res 2007, 4(4):427-36.
78. Lemere CA: Developing novel immunogens for a safe and effective Alzheimer's disease vaccine. Prog Brain Res 2009, 175:83-93.

79. Litvan I, Halliday G, Hallett M, Goetz CG, Rocca W, Duyckaerts C Ben-Shlomo Y, Dickson DW, Lang AE, Chesselet MF, Langston WJ, Di Monte DA, Gasser T, Hagg T, Hardy J, Jenner P, Melamed E, Myers RH, Parker D Jr, Price DL: The etiopathogenesis of Parkinson disease and suggestions for future research. Part I. J Neuropathol Exp Neurol 2007, 66(4):25I-7.

80. Banati RB, Daniel SE, Blunt SB: Glial pathology but absence of apoptotic nigral neurons in long-standing Parkinson's disease. Mov Disord 1998, 13(2):221-7.

8I. Gerhard A, Pavese N, Hotton G, Turkheimer F, Es M, Hammers A, Eggert $K$, Oertel W, Banati RB, Brooks DJ: In vivo imaging of microglial activation with [IIC](R)-PKIII 95 PET in idiopathic Parkinson's disease. Neurobiol Dis 2006, 2 I(2):404- 12.

82. Hunot $S$, Dugas N, Faucheux B, Hartmann A, Tardieu M, Debre P, Agid $Y$, Dugas B, Hirsch EC: FcepsilonRII/CD23 is expressed in Parkinson's disease and induces, in vitro, production of nitric oxide and tumor necrosis factor-alpha in glial cells. J Neurosci 1999, 19(9):3440-7.

83. McGeer PL, Itagaki S, Boyes BE, McGeer EG: Reactive microglia are positive for HLA-DR in the substantia nigra of Parkinson's and Alzheimer's disease brains. Neurology 1988, 38(8): | $285-9 \mid$.

84. Vawter MP, Dillon-Carter O, Tourtellotte WW, Carvey P, Freed WJ: TGFbetal and TGFbeta2 concentrations are elevated in Parkinson's disease in ventricular cerebrospinal fluid. Exp Neurol 1996, 142(2):313-22.

85. Ferger B, Leng A, Mura A, Hengerer B, Feldon J: Genetic ablation of tumor necrosis factor-alpha (TNF-alpha) and pharmacological inhibition of TNF-synthesis attenuates MPTP toxicity in mouse striatum. J Neurochem 2004, 89(4):822-33.

86. Rousselet E, Callebert J, Parain K, Joubert C, Hunot S, Hartmann A, Jacque C, Perez-Diaz F, Cohen-Salmon C, Launay JM, Hirsch EC: Role of TNF-alpha receptors in mice intoxicated with the parkinsonian toxin MPTP. Exp Neurol 2002, I77(I):183-92.

87. Sriram K, Matheson JM, Benkovic SA, Miller DB, Luster MI, O'Callaghan JP: Mice deficient in TNF receptors are protected against dopaminergic neurotoxicity: implications for Parkinson's disease. Faseb J 2002, I6(II): I474-1476.

88. Barcia C, de Pablos V, Bautista-Hernandez V, Sanchez-Bahillo A, Bernal I, Fernandez-Villalba E, Martin J, Banon R, Fernandez-Barreiro A, Herrero MT: Increased plasma levels of TNF-alpha but not of ILI-beta in MPTP-treated monkeys one year after the MPTP administration. Parkinsonism Relat Disord 2005, I I (7):435-439.

89. Gao HM, Jiang J, Wilson B, Zhang W, Hong JS, Liu B: Microglial activation-mediated delayed and progressive degeneration of rat nigral dopaminergic neurons: relevance to Parkinson's disease. J Neurochem 2002, 8 I (6): I285-I297.

90. Ling Z, Gayle DA, Ma SY, Lipton JW, Tong CW, Hong JS, Carvey PM: In utero bacterial endotoxin exposure causes loss of tyrosine hydroxylase neurons in the postnatal rat midbrain. Mov Disord 2002, I 7(I): I I6-124.

91. McCoy MK, Martinez TN, Ruhn KA, Szymkowski DE, Smith CG, Botterman BR, Tansey KE, Tansey MG: Blocking soluble tumor necrosis factor signaling with dominant-negative tumor necrosis factor inhibitor attenuates loss of dopaminergic neurons in models of Parkinson's disease. J Neurosci 2006, 26(37):9365-9375

92. McCoy MK, Ruhn KA, Martinez TN, McAlpine FE, Blesch A, Tansey MG: Intranigral lentiviral delivery of dominant-negative TNF attenuates neurodegeneration and behavioral deficits in hemiparkinsonian rats. Mol Ther 2008, I6(9): I572-1579.

93. Boka G, Anglade P, Wallach D, Javoy-Agid F, Agid Y, Hirsch EC: Immunocytochemical analysis of tumor necrosis factor and its receptors in Parkinson's disease. Neurosci Lett 1994, I72(12): $15 \mid-154$

94. Tartaglia LA, Rothe M, Hu YF, Goeddel DV: Tumor necrosis factor's cytotoxic activity is signaled by the p55 TNF receptor. Cell 1993, 73(2):213-216

95. Aloe L, Fiore M: TNF-alpha expressed in the brain of transgenic mice lowers central tyroxine hydroxylase immunoreactivity and alters grooming behavior. Neurosci Lett 1997, 238(I-2):65-68. 
96. Carvey PM, Chen EY, Lipton JW, Tong CW, Chang QA, Ling ZD: Intra-parenchymal injection of tumor necrosis factor-alpha and interleukin I-beta produces dopamine neuron loss in the rat. J Neural Transm 2005, I I 2(5):60 I-6I2.

97. Gayle DA, Ling Z, Tong C, Landers T, Lipton JW, Carvey PM: Lipopolysaccharide (LPS)-induced dopamine cell loss in culture: roles of tumor necrosis factor-alpha, interleukin-I beta, and nitric oxide. Brain Res Dev Brain Res 2002, I 33(1):27-35.

98. Ling ZD, Potter ED, Lipton JW, Carvey PM: Differentiation of mesencephalic progenitor cells into dopaminergic neurons by cytokines. Exp Neurol I998, I 49(2):4I I-423.

99. McGuire SO, Ling ZD, Lipton JW, Sortwell CE, Collier TJ, Carvey PM: Tumor necrosis factor alpha is toxic to embryonic mesencephalic dopamine neurons. Exp Neurol 200I, 169(2):219-230.

100. Hakansson A, Westberg L, Nilsson S, Buervenich S, Carmine A, Holmberg B, Sydow O, Olson L, Johnels B, Eriksson E, et al.: Investigation of genes coding for inflammatory components in Parkinson's disease. Mov Disord 2005, 20(5):569-573.

10I. Hakansson A, Westberg L, Nilsson S, Buervenich S, Carmine A, Holmberg B, Sydow O, Olson L, Johnels B, Eriksson E, et al.: Interaction of polymorphisms in the genes encoding interleukin-6 and estrogen receptor beta on the susceptibility to Parkinson's disease. Am J Med Genet B Neuropsychiatr Genet 2005, I 33(I):88-92.

102. Kruger R, Hardt C, Tschentscher F, Jackel S, Kuhn W, Muller T, Werner J, Woitalla D, Berg D, Kuhnl N, et al.: Genetic analysis of immunomodulating factors in sporadic Parkinson's disease. J Neural Transm 2000, 107(5):553-562.

103. Nishimura M, Kuno S, Kaji R, Yasuno K, Kawakami H: GlutathioneS-transferase-I and interleukin-I beta gene polymorphisms in Japanese patients with Parkinson's disease. Mov Disord 2005, 20(7):90I-902.

104. Nishimura M, Mizuta I, Mizuta E, Yamasaki S, Ohta M, Kaji R, Kuno S: Tumor necrosis factor gene polymorphisms in patients with sporadic Parkinson's disease. Neurosci Lett 200 I, 3 I I (I): I-4.

105. Block ML, Zecca L, Hong JS: Microglia-mediated neurotoxicity: uncovering the molecular mechanisms. Nat Rev Neurosci 2007, 8(I):57-69.

106. Ito S, Sawada M, Haneda M, Ishida Y, Isobe K: Amyloid-beta peptides induce several chemokine mRNA expressions in the primary microglia and Ra2 cell line via the PI3K/Akt and/or ERK pathway. Neurosci Res 2006, 56(3):294-299.

107. Kim YS, Joh TH: Microglia, major player in the brain inflammation: their roles in the pathogenesis of Parkinson's disease. Exp Mol Med 2006, 38(4):333-347.

108. Sawada M, Imamura K, Nagatsu T: Role of cytokines in inflammatory process in Parkinson's disease. J Neural Transm Suppl 2006, 70:373-38I.

109. Group THsDCR: A novel gene containing a trinucleotide repeat that is expanded and unstable on Huntington's disease chromosomes. Cell 1993, 72:97|-983.

1 10. Dalrymple A, Wild EJ, Joubert R, Sathasivam K, Bjorkqvist M, Petersen A, Jackson GS, Isaacs JD, Kristiansen M, Bates GP, et al.: Proteomic profiling of plasma in Huntington's disease reveals neuroinflammatory activation and biomarker candidates. Journal of proteome research 2007, 6(7):2833-2840.

1II. Hodges A, Strand AD, Aragaki AK, Kuhn A, Sengstag T, Hughes G, Elliston LA, Hartog C, Goldstein DR, Thu D, et al.: Regional and cellular gene expression changes in human Huntington's disease brain. Hum Mol Genet 2006, I 5(6):965-977.

II2. Singhrao SK, Neal JW, Morgan BP, Gasque P: Increased complement biosynthesis by microglia and complement activation on neurons in Huntington's disease. Exp Neurol 1999, I 59(2):362-376.

113. Bjorkqvist M, Wild EJ, Thiele J, Silvestroni A, Andre R, Lahiri N, Raibon E, Lee RV, Benn CL, Soulet D, et al:: A novel pathogenic pathway of immune activation detectable before clinical onset in Huntington's disease. J Exp Med 2008, 205(8): | 869-1877.

1 14. Tai YF, Pavese N, Gerhard A, Tabrizi SJ, Barker RA, Brooks DJ, Piccini $\mathrm{P}$ : Microglial activation in presymptomatic Huntington's disease gene carriers. Brain 2007, I 30(Pt 7): 1759-1766.

115. Pavese N, Gerhard A, Tai YF, Ho AK, Turkheimer F, Barker RA, Brooks DJ, Piccini P: Microglial activation correlates with severity in Huntington disease: a clinical and PET study. Neurology 2006, 66(II):1638-1643.

116. Sapp E, Kegel KB, Aronin N, Hashikawa T, Uchiyama Y, Tohyama K, Bhide PG, Vonsattel JP, DiFiglia M: Early and progressive accumu- lation of reactive microglia in the Huntington disease brain. J Neuropathol Exp Neurol 200I, 60(2):16I-I72.

117. Cleren C, Calingasan NY, Chen J, Beal MF: Celastrol protects against MPTP- and 3-nitropropionic acid-induced neurotoxicity. J Neurochem 2005, 94(4):995-1004.

1 18. Norflus F, Nanje A, Gutekunst CA, Shi G, Cohen J, Bejarano M, Fox J, Ferrante RJ, Hersch SM: Anti-inflammatory treatment with acetylsalicylate or rofecoxib is not neuroprotective in Huntington's disease transgenic mice. Neurobiol Dis 2004, I7(2):319-325

119. Sugars KL, Rubinsztein DC: Transcriptional abnormalities in Huntington disease. Trends Genet 2003, 19(5):233-238.

120. Khoshnan A, Ko J, Watkin EE, Paige LA, Reinhart PH, Patterson PH: Activation of the lkappaB kinase complex and nuclear factor-kappaB contributes to mutant huntingtin neurotoxicity. J Neurosci 2004, 24(37):7999-8008.

12I. Henkel JS, Engelhardt Jl, Siklos L, Simpson EP, Kim SH, Pan T, Goodman JC, Siddique T, Beers DR, Appel SH: Presence of dendritic cells, MCP-I, and activated microglia/macrophages in amyotrophic lateral sclerosis spinal cord tissue. Ann Neurol 2004, 55(2):22I-235.

122. Kawamata T, Akiyama H, Yamada T, McGeer PL: Immunologic reactions in amyotrophic lateral sclerosis brain and spinal cord tissue. Am J Pathol 1992, I40(3):69I-707.

123. Turner MR, Cagnin A, Turkheimer FE, Miller CC, Shaw CE, Brooks DJ, Leigh PN, Banati RB: Evidence of widespread cerebral microglial activation in amyotrophic lateral sclerosis: an [IIC](R)-PKIII95 positron emission tomography study. Neurobiol Dis 2004, 1 5(3):601-609.

124. Henkel JS, Beers DR, Siklos L, Appel SH: The chemokine MCP-I and the dendritic and myeloid cells it attracts are increased in the mSODI mouse model of ALS. Mol Cell Neurosci 2006 , 3 I (3):427-437.

125. McManus CM, Liu JS, Hahn MT, Hua LL, Brosnan CF, Berman JW, Lee SC: Differential induction of chemokines in human microglia by type I and II interferons. Glia 2000, 29(3):273-280.

126. Kuhle J, Lindberg RL, Regeniter A, Mehling M, Steck AJ, Kappos L, Czaplinski A: Increased levels of inflammatory chemokines in amyotrophic lateral sclerosis. Eur J Neurol 2009, I 6(6):77|-774

127. Keizman D, Rogowski O, Berliner S, Ish-Shalom M, Maimon N, Nefussy B, Artamonov I, Drory VE: Low-grade systemic inflammation in patients with amyotrophic lateral sclerosis. Acta Neurol Scand 2009, I I 9(6):383-389.

128. Rosen DR, Siddique T, Patterson D, Figlewicz DA, Sapp P, Hentati A, Donaldson D, Goto J, O'Regan JP, Deng HX, et al:: Mutations in Cu/ Zn superoxide dismutase gene are associated with familial amyotrophic lateral sclerosis. Nature 1993, 362(6415):59-62.

129. Clement AM, Nguyen MD, Roberts EA, Garcia ML, Boillee S, Rule M, McMahon AP, Doucette W, Siwek D, Ferrante RJ, et al:: Wild-type nonneuronal cells extend survival of SODI mutant motor neurons in ALS mice. Science 2003, 302(5642): I I3-I I7.

130. Lino MM, Schneider C, Caroni P: Accumulation of SODI mutants in postnatal motoneurons does not cause motoneuron pathology or motoneuron disease. J Neurosci 2002, 22( I 2):4825-4832.

131. Pramatarova A, Laganiere J, Roussel J, Brisebois K, Rouleau GA: Neuron-specific expression of mutant superoxide dismutase $I$ in transgenic mice does not lead to motor impairment. J Neurosci 200I, 2 I ( I0):3369-3374.

132. Sargsyan SA, Monk PN, Shaw PJ: Microglia as potential contributors to motor neuron injury in amyotrophic lateral sclerosis. Glia 2005, 5 I (4):24I-253.

133. Beers DR, Henkel JS, Xiao Q, Zhao W, Wang J, Yen AA, Siklos L, McKercher SR, Appel SH: Wild-type microglia extend survival in PU.I knockout mice with familial amyotrophic lateral sclerosis. Proc Natl Acad Sci USA 2006, I03(43): 1602 I-16026.

134. Boillee S, Yamanaka K, Lobsiger CS, Copeland NG, Jenkins NA, Kassiotis G, Kollias G, Cleveland DW: Onset and progression in inherited ALS determined by motor neurons and microglia. Science 2006, 3 | 2(5778): | 389-1392.

135. Weydt P, Yuen EC, Ransom BR, Moller T: Increased cytotoxic potential of microglia from ALS-transgenic mice. Glia 2004, 48(2): $179-182$.

136. Ferri A, Nencini M, Battistini S, Giannini F, Siciliano G, Casali C, Damiano MG, Ceroni M, Chio A, Rotilio G, et al.: Activity of protein phosphatase calcineurin is decreased in sporadic and familial 
amyotrophic lateral sclerosispatients. I Neurochem 2004, 90(5): $1237-1242$.

137. Elliott JL: Cytokine upregulation in a murine model of familial amyotrophic lateral sclerosis. Brain Res Mol Brain Res 200 I, 95(I2): $172-178$.

138. Yoshihara T, Ishigaki S, Yamamoto M, Liang Y, Niwa J, Takeuchi H, Doyu M, Sobue G: Differential expression of inflammation- and apoptosis-related genes in spinal cords of a mutant SODI transgenic mouse model of familial amyotrophic lateral sclerosis. J Neurochem 2002, 80(I): 158-167.

139. Poloni M, Facchetti D, Mai R, Micheli A, Agnoletti L, Francolini G, Mora G, Camana C, Mazzini L, Bachetti T: Circulating levels of tumour necrosis factor-alpha and its soluble receptors are increased in the blood of patients with amyotrophic lateral sclerosis. Neurosci Lett 2000, 287(3):2I I-2I4.

140. West M, Mhatre M, Ceballos A, Floyd RA, Grammas P, Gabbita SP, Hamdheydari L, Mai T, Mou S, Pye QN, et al.: The arachidonic acid 5-lipoxygenase inhibitor nordihydroguaiaretic acid inhibits tumor necrosis factor alpha activation of microglia and extends survival of G93A-SODI transgenic mice. J Neurochem 2004, 91 (I):133-143.

14I. Tikka TM, Vartiainen NE, Goldsteins G, Oja SS, Andersen PM, Marklund SL, Koistinaho J: Minocycline prevents neurotoxicity induced by cerebrospinal fluid from patients with motor neurone disease. Brain 2002, I 25(Pt 4):722-73I.

142. Nguyen MD, Julien JP, Rivest S: Induction of proinflammatory molecules in mice with amyotrophic lateral sclerosis: no requirement for proapoptotic interleukin-I beta in neurodegeneration. Ann Neurol 200I, 50(5):630-639.

Publish with Bio Med Central and every scientist can read your work free of charge

"BioMed Central will be the most significant development for disseminating the results of biomedical research in our lifetime. "

Sir Paul Nurse, Cancer Research UK

Your research papers will be:

- available free of charge to the entire biomedical community

- peer reviewed and published immediately upon acceptance

- cited in PubMed and archived on PubMed Central

- yours - you keep the copyright

Submit your manuscript here:

http://www.biomedcentral.com/info/publishing_adv.asp
BioMedcentral 